\title{
Keanekaragaman dan kelimpahan kumbang cerambycid (Coleoptera: Cerambycidae) di Cagar Alam Pangandaran, Jawa Barat
}

\author{
Diversity and abundance of cerambycid beetles (Coleoptera: \\ Cerambycidae) in Pangandaran Nature Reserve, West Java
}

\author{
Septiani Dewi Ariska ${ }^{1}$, Tri Atmowidi ${ }^{*}$, Woro Anggraitoningsih Noerdjito² \\ ${ }^{1}$ Departemen Biologi, Fakultas Matematika dan Ilmu Pengetahuan Alam, IPB University \\ Jalan Agatis, Kampus IPB Dramaga, Bogor 16680 \\ ${ }^{2}$ Bidang Zoologi, Pusat Penelitian Biologi, LIPI \\ Jalan Raya Bogor Km 46, Cibinong 16003
}

(diterima September 2020, disetujui Maret 2021)

\begin{abstract}
ABSTRAK
Struktur komunitas kumbang cerambycid di suatu kawasan berkaitan dengan heterogenitas tumbuhan berkayu. Kawasan Cagar Alam Pangandaran merupakan hutan yang berbentuk semenanjung yang memiliki komunitas hewan dan tumbuhan yang khas. Penelitian ini bertujuan untuk menganalisis keanekaragaman dan kelimpahan kumbang cerambicid di kawasan Cagar Alam Pangandaran. Perangkap cabang tumbuhan nangka (Artocarpus heterophyllus) dan awar-awar (Ficus septica) digunakan untuk koleksi kumbang. Perangkap ini diikatkan pada cabang pohon atau batang kayu pada ketinggian sekitar 1,5 m dari permukaan tanah. Pemasangan perangkap dilakukan di kawasan Taman Wisata Alam dan Cagar Alam masing-masing 2 lokasi. Koleksi sampel kumbang dilakukan dengan metode beating. Dalam penelitian ini dikoleksi 574 individu kumbang cerambycid yang termasuk dalam 1 subfamili, 8 tribe, 12 genus, dan 20 spesies. Keanekaragaman spesies kumbang tertinggi ditemukan di Taman Wisata Alam-1 $\left(\mathrm{H}^{\prime}=2,09, \mathrm{E}=0,74\right)$, diikuti Cagar Alam-2 $\left(\mathrm{H}^{\prime}=1,75, \mathrm{E}=0,68\right)$, Taman Wisata Alam-2 $\left(\mathrm{H}^{\prime}=1,70, \mathrm{E}=0,71\right)$, dan Cagar Alam-1 $\left(\mathrm{H}^{\prime}=\right.$ $1,52, \mathrm{E}=0,69)$. Spesies kumbang yang ditemukan dengan kelimpahan tinggi ialah Sybra binotata Gahan (229 individu), Nyctimenius javanus (74 individu), Atimura bacillina Pascoe (67 individu), dan Acalolepta rusticatrix (Fabricius) (45 individu). Jumlah individu kumbang yang diperoleh dengan perangkap Artocarpus (342 individu) lebih banyak dibandingkan dengan perangkap Ficus (232 individu). Dalam penelitian ini juga teridentifikasi tujuh spesies kumbang endemik pulau Jawa, yaitu Myagrus javanicus Breuning, Cacia curta Breuning, Sybra obliquefasciata Breuning, Sybra fuscotriangularis Breuning, Pterolophia triangularis Breuning, N. javanus, dan Exocentrus artocarpi Fisher.
\end{abstract}

Kata kunci: Artocarpus, cerambycid, Ficus, keanekaragaman, Pangandaran

\begin{abstract}
The community structure of cerambycid beetles in an area is closely related to the heterogeneity of woody plants. Pangandaran Nature Reserve is forest located in the peninsula and has unique fauna and flora communities. The study aims to analyze the diversity and abundance of cerambycid beetles in the Pangandaran Nature Reserve. To attract the cerambycid beetles, we used branches of jackfruit (Artocarpus heterophyllus) and fig (Ficus septica) as traps. Traps were tied in a tree or log about $1.5 \mathrm{~m}$ from the ground in the Nature Recreation Park and the Nature Reserve, each area with 2
\end{abstract}

\footnotetext{
*Penulis korespondensi: Tri Atmowidi. Departemen Biologi, Fakultas Matematika dan Ilmu Pengetahuan Alam, IPB University Jalan Agatis, Kampus IPB Dramaga, Bogor 16680, Tel: 0251-8622833, Faks: 0251-8622833, Email: atmowidi@apps.ipb.ac.id
} 


\begin{abstract}
locations. Collection of beetles werecarried outbybeating method.Atotal of 574 individualscerambycid beetles were found, belonging to 1 subfamily, 8 tribes, 12 genera, and 20 species. The highest species diversity of beetles was found in Nature Recreation Park-1 $\left(\mathrm{H}^{\prime}=2.09, \mathrm{E}=0.74\right)$, followed by Nature Reserve-2 $\left(\mathrm{H}^{\prime}=1.75, \mathrm{E}=0.68\right)$, Nature Recreation Park-2 $\left(\mathrm{H}^{\prime}=1.70, \mathrm{E}=0.71\right)$, and Nature Reserve-1 $\left(\mathrm{H}^{\prime}=1.52, \mathrm{E}=0.69\right)$. Four species of beetles found in high abundance were Sybra binotata Gahan (229 individuals), Nyctimenius javanus (74 individuals), Atimura bacillina Pascoe (67 individuals), and Acalolepta rusticatrix (Fabricius) (45 individuals). The number of individual beetles collected in Artocarpus (342 individuals) was higher than Ficus traps (232 individuals). This study identified seven endemic beetles of Java, i.e., Myagrus javanicus Breuning, Cacia curta Breuning, Sybra obliquefasciata Breuning, Sybra fuscotriangularis Breuning, Pterolophia triangularis Breuning, $N$. javanus, and Exocentrus artocarpi Fisher.
\end{abstract}

Key words: Artocarpus, cerambycid, diversity, Ficus, Pangandaran

\section{PENDAHULUAN}

Kumbang cerambycid (Coleoptera: Cerambycidae) merupakan salah satu kelompok terbesar kumbang pengebor kayu (Noerdjito et al. 2003). Kumbang ini mudah dikenal karena memiliki antena dengan panjang mencapai lebih dari setengah panjang tubuhnya. Kumbang antena panjang mempunyai bentuk mata yang menakik (notched), seolah-olah mata mengelilingi pangkal antena, dengan tubuh memanjang (panjang 3$73 \mathrm{~mm}$ ) (Borror et al. 1989). Panjang antena pada kumbang jantan dewasa dapat mencapai dua kali atau lebih dari panjang tubuhnya (Noerdjito et al. 2003).

Kumbang betina meletakkan telur di bawah kulit kayu pada pangkal cabang. Larva kumbang ini hidup sebagai pengebor kayu (Makihara 1999) yang dapat menyebabkan kerusakan, bahkan kematian pohon (Borror et al. 1989). Beberapa spesies kumbang ini juga mengebor batang bambu dan berbagai spesies rumput (Noerdjito et al. 2005). Kumbang dewasa hidup sebagai pemakan nektar, pucuk daun, dan kulit kayu (Noerdjito 2011).

Keanekaragaman kumbang cerambycid di suatu kawasan berkaitan dengan heterogenitas tumbuhan (La Mantia et al. 2010). Keberadaan kayu dan ranting lapuk juga berkorelasi positif dengan keanekaragaman kumbang cerambycid (Koneri et al. 2010). Beberapa spesies kumbang ini hanya ditemukan di kawasan hutan dan beberapa spesies lainnya ditemukan di hutan terdegradasi. Oleh karena itu, struktur komunitas kumbang cerambycid dapat digunakan sebagai bioindikator kawasan hutan (Noerdjito et al. 2004).
Penelitian tentang keanekaragaman kumbang cerambycid di Jawa telah dilaporkan sebelumnya, yaitu di Taman Nasional Gunung Halimun (150 spesies) (Makihara \& Noerdjito 2002), Taman Nasional Gunung Ciremai (38 spesies) (Noerdjito 2008), Kebun Raya Bogor (13 spesies) (Noerdjito 2010), dan Gunung Salak (38 spesies) (Noerdjito 2012). Sekitar 1.200 spesimen kumbang cerambycid tersimpan di Museum Zoologicum Bogoriense (MZB), Pusat Penelitian Biologi, LIPI.

Kawasan Cagar Alam Pangandaran merupakan kawasan hutan hujan dengan luas sekitar 497 ha, yang sebagian di antaranya (37,70 ha) merupakan Taman Wisata Alam. Kawasan Cagar Alam Pangandaran memiliki tipe ekosistem hutan pantai. Kawasan ini memiliki topografi landai dan berbukit dengan ketinggian 0-75 m dpl. Kawasan hutan ini sangat unik karena berupa semenanjung yang dikelilingi pantai di bagian barat dan timur sehingga memiliki komunitas hewan dan tumbuhan yang khas. Laporan mengenai keanekaragaman hayati di kawasan ini antara lain primata, mamalia besar, dan vegetasi. Laporan keanekaragaman hayati serangga, seperti kumbang kotoran (dung beetle) di hutan Pangandaran juga sudah dilaporkan oleh Priawandiputra et al. (2020), yaitu sebanyak 17 spesies dan Onthophagus babirussa (Eschscholtz) merupakan spesies dominan. Keanekaragaman kumbang cerambycid di kawasan hutan Pangandaran belum pernah di laporkan sebelumnya. Penelitian ini bertujuan menganalisis keanekaragaman dan kelimpahan kumbang cerambycid di kawasan Cagar Alam Pangandaran. Data penelitian ini diharapkan dapat menambah informasi tentang keanekaragaman kumbang cerambycid dataran rendah, khususnya di Jawa. 


\section{BAHAN DAN METODE}

\section{Deskripsi lokasi penelitian}

Koleksi kumbang cerambycid dilakukan di empat lokasi, yaitu 2 lokasi di Taman Wisata Alam (TWA-1, TWA-2) dan 2 lokasi di Cagar Alam (CA-1,CA-2). Lokasi TWA-1 (07 42' 43.0" LS dan $108^{\circ} 39^{\prime} 73.0^{\prime}$ ' BT) dengan ketinggian $37 \mathrm{~m} \mathrm{dpl}$ terletak dekat pantai timur yang berbatasan dengan wilayah Cagar Alam. Tumbuhan di lokasi ini didominasi oleh pohon dengan kanopi rapat, seperti ki buaya (Leea indica), kenanga (Cananga odorata), caruy (Pterospermum javanicum), ki kores (Physchotria viridiflora), ki minyak (Casearia sp.), dan jati (Tectona grandis). Lokasi TWA-2 (07' 42' 41.2" LS dan $108^{\circ} 39^{\prime}$ 60.2 " BT) dengan ketinggian $43 \mathrm{~m} \mathrm{dpl}$ terletak di dekat situs peninggalan sejarah Batu Kalde. Lokasi ini juga didominasi tumbuhan berkanopi rapat, di antaranya kondang (Ficus variegata), jati (T. grandis), mahoni (Swietenia mahagoni), caruy (P. javanicum), hantap heulang (Sterculia coccinea), dan jambu alas (Syzygium densiflora). Lokasi CA-1 (07 42' 64.8' LS dan $108^{\circ} 39^{\prime}$ 36.3 " BT) dengan ketinggian $65 \mathrm{~m}$ dpl merupakan kawasan semi-terbuka dengan topografi sedikit berbukit. Vegetasi yang dijumpai di antaranya jati (T. grandis), beringin (Ficus benjamina), seruni (Chrysanthemum indicum), ki hujan (Samanea saman), singkil (Premna spp.), sembung (Blumea balsamifera), kelepu (Nauclea orientalis), kiara (Ficus microcarpa), salam (Eugenia polyantha), dan perdu. Lokasi CA-2 (07 $42^{\prime}$ ' 50.4" 'LS dan $108^{\circ}$ 39' 14.6" BT) dengan ketinggian $23 \mathrm{~m}$ dpl. Lokasi ini terletak di wilayah pantai barat, dekat pantai pasir putih yang ramai dikunjungi wisatawan. Lokasi ini didominasi pohon dengan kanopi rapat, seperti cangkuang (Pandanus furcatus), loa (Ficus racemosa), beringin ( $F$. benjamina), kondang (F. variegata), salam (E. polyantha), caruy ( $P$. javanicum), dan kopo (Syzygium cymosum). Kondisi lingkungan di kawasan cagar alam Pangandaran selama pengambilan sampel kumbang adalah dengan kisaran suhu $30-32{ }^{\circ} \mathrm{C}$, kelembaban 70-80\%, kecepatan angin $0,0-1,3 \mathrm{~m} /$ detik, dan intensitas cahaya 171,7-4306,5 lux.

\section{Koleksi kumbang}

Koleksi kumbang cerambycid menggunakan perangkap cabang nangka (Artocarpus heterophyllus) dan awar-awar (Ficus septica) (Noerdjito et al. 2003). Perangkap tersebut berupa satu ikat cabang segar (5 cabang beserta daunnya, panjang sekitar $1 \mathrm{~m}$ ) yang diikatkan pada cabang pohon atau batang kayu pada ketinggian sekitar 1,5 $\mathrm{m}$ dari permukaan tanah. Perangkap tersebut dibiarkan sampai layu untuk menarik kehadiran kumbang. Di setiap lokasi, masing-masing dipasang 10 perangkap Artocarpus dan Ficus berselang-seling dengan jarak antar perangkap $50 \mathrm{~m}$. Koleksi kumbang dilakukan pada hari ke$3,6,9$, dan 12 setelah pemasangan perangkap. Kumbang dikoleksi dengan metode beating, yaitu dengan memukul atau menggoyang perangkap yang di bawahnya diberi kain putih berukuran $2 \mathrm{~m} \times 1 \mathrm{~m}$. Kumbang yang terkumpul pada kain dikoleksi, dimasukkan dalam botol, dan dibius dengan ethyl acetat. Spesimen kumbang diawetkan secara kering.

\section{Preservasi spesimen kumbang}

Preservasi spesimen kumbang mengacu pada Borror et al. (1989). Spesimen kumbang yang berukuran lebih dari $10 \mathrm{~mm}$ dipinning, sedangkan kumbang yang berukuran kurang dari $10 \mathrm{~mm}$ ditempelkan pada point card. Setelah pinning, dilanjutkan dengan labelling yang meliputi lokasi, waktu koleksi, metode koleksi, dan nama kolektor. Spesimen kumbang kemudian dimasukkan ke dalam oven pada suhu $35^{\circ} \mathrm{C}$ selama satu minggu. Selanjutnya, spesimen dimasukkan ke dalam freezer selama satu minggu sebelum dilakukan identifikasi.

\section{Identifikasi spesimen kumbang}

Spesimen kumbang cerambycid diidentifikasi sampai level genus berdasarkan Cherepanov (1990) dan spesies berdasarkan Makihara \& Noerdjito (2002) dan Noerdjito et al. (2004). Identifikasi kumbang juga dilakukan dengan membandingkan spesimen koleksi Museum Zoologicum Bogoriense (MZB). Semua spesimen kumbang yang telah diidentifikasi disimpan di MZB, LIPI Cibinong, Jawa Barat.

\section{Analisis data}

Data kumbang cerambycid dianalisis dengan indeks keanekaragaman Shannon-Wiener ( $\left.\mathrm{H}^{\prime}\right)$, indeks kemerataan (E), dan indeks dominansi Simpson (D) (Magurran 2004). Komunitas 
kumbang yang ditemukan di masing-masing lokasi dikelompokkan berdasarkan analisis clustering dengan algoritma unweighted pair group method with arithmetic mean (UPGMA) berdasarkan kesamaan Bray-Curtis, yang terdapat pada program Paleontological Statistics (PAST) versi 1.93 (Hammer et al. 2001). Rumus-rumus yang digunakan adalah sebagai berikut:

$$
\mathrm{H}^{\prime}=-\Sigma \text { PilnPi, dengan }
$$

$\mathrm{H}^{\prime}$ : indeks keanekaragaman Shannon-Wiener; $\Sigma$ : jumlah spesies; Pi: ni/N; ni: jumlah individu spesies ke-i; N: jumlah individu total; ln: logaritma natural.

$$
\mathrm{E}=\mathrm{H}^{\prime} / \operatorname{lnS} \text {, dengan }
$$

E: indeks kemerataan (evenness); H': indeks keanekaragaman Shannon-Wiener; ln: logaritma natural; S: jumlah spesies.

$$
\mathrm{D}=\Sigma \mathrm{Pi}^{2} \text {, dengan }
$$

D: indeks dominansi Simpson; Pi: ni/N; ni: jumlah individu spesies ke-i; N: jumlah individu total.

\section{HASIL}

\section{Keanekaragaman kumbang cerambycid}

Total individu kumbang cerambycid yang dikoleksi dari kawasan Pangandaran sebanyak 574 individu yang termasuk dalam 1 subfamili, 8 tribe, 12 genus, dan 20 spesies (Tabel 1). Tiga ratus individu kumbang dikoleksi dari kawasan Cagar Alam dan 274 individu dari kawasan Taman Wisata Alam. Spesies kumbang dengan kelimpahan tinggi, yaitu Sybra binotata Gahan (229 individu), Nyctimenius javanus (74 individu), Atimura bacillina Pascoe (67 individu), dan Acalolepta rusticatrix (Fabricius)(45 individu). Jumlah individu kumbang tertinggi ditemukan di CA-1 (206 individu) dan terendah di CA-2 (94 individu). Kumbang yang ditemukan dominan di lokasi CA-1 (daerah semi-terbuka) merupakan spesies yang berukuran kecil, seperti A. bacillina, Sybra alternans (Wiedemann), S. binotata, Pterolophia uniformis (Pascoe), dan P. melanura (Pascoe). Di lokasi CA-1 juga dikoleksi Sybra lateralis Breuning yang tidak ditemukan di lokasi lain. Spesies kumbang yang hanya ditemukan di satu lokasi pengamatan ialah Cereopsius javanus
Breuning (TWA-1), S. lateralis (CA-1), Sybra obliquefasciata Breuning (CA-2), dan Exocentrus artocarpi Fisher (CA-2) dengan kelimpahan yang sangat rendah (1 individu).

Keanekaragaman spesies kumbang tertinggi ditemukan di TWA-1 $\left(\mathrm{H}^{\prime}=2,09, \mathrm{E}=0,74\right.$, dan 17 spesies) dengan nilai dominansi paling rendah (D $=0,20)$, diikuti oleh CA-2 $\left(\mathrm{H}^{\prime}=1,75, \mathrm{E}=0,68\right.$, dan 13 spesies), TWA-2 ( $\mathrm{H}^{\prime}=1,70, \mathrm{E}=0,71$ dan 11 spesies), dan CA-1 ( $\mathrm{H}^{\prime}=1,52, \mathrm{E}=0,69$, dan 9 spesies) dengan nilai dominansi paling besar (D $=0,28)$ (Tabel 2). Berdasarkan analisis UPGMA, spesies kumbang cerambycid di TWA membentuk tiga kelompok. Kelompok pertama adalah Taman Wisata Alam (TWA-1 dan TWA-2) yang didominasi oleh A. rusticatrix, Myagrus javanicus Breuning, Cacia curta Breuning, C. herbaceae, Gnoma confusa J. Thomson, N. javanus, Pterolophia triangularis Breuning, dan Pothyne vittata Aurivillius. Kelompok kedua adalah CA-2 yang didominasi oleh A. rusticatrix, G. confusa, S. obliquefasciata, dan E. artocarpi. Kelompok ketiga adalah CA-1 yang didominasi oleh $A$. bacillina, $S$. alternans, $S$. lateralis, S. binotata, $P$. uniformis, dan P. melanura) (Gambar 1).

Jumlah individu kumbang yang dikoleksi dengan perangkap Artocarpus (342 individu) lebih banyak dibandingkan dengan perangkap Ficus (232 individu) (Gambar 2). Dua belas spesies kumbang berhasil dikoleksi dari kedua perangkap dan 8 spesies dikoleksi dari perangkap Artocarpus. Spesies dominan yang dikoleksi dengan perangkap Artocarpus ialah G. confusa, A. bacillina, S. binotata, dan P. uniformis, sedangkan spesies dominan yang dikoleksi dengan perangkap Ficus ialah $A$. rusticatrix dan $P$. vittata. Jumlah individu terbanyak dikoleksi dengan perangkap Artocarpus terjadi pada hari ke 6 (136 individu), sedangkan dengan perangkap Ficus terjadi pada hari ke-9 (101 individu) (Gambar 3A). Jumlah spesies kumulatif yang dikoleksi dengan kedua perangkap meningkat dari hari ke-3 sampai hari ke-12 (Gambar 3B).

\section{PEMBAHASAN}

Spesies kumbang cerambycid yang dikoleksi di kawasan Pangandaran termasuk dalam Subfamili Lamiinae. Kumbang Lamiinae dicirikan dengan 
Tabel 1. Spesies kumbang cerambycid yang dikoleksi di kawasan Pangandaran. TWA: Taman Wisata Alam; CA: Cagar Alam; AT: Artocarpus trap; FT: Ficus trap

\begin{tabular}{|c|c|c|c|c|c|c|c|c|c|c|}
\hline \multirow{3}{*}{$\begin{array}{l}\text { Subfamili } \\
\text { Tribe } \\
\text { Genus (spesies) }\end{array}$} & \multicolumn{4}{|c|}{ Taman Wisata Alam } & \multicolumn{4}{|c|}{ Cagar Alam } & \multirow{2}{*}{\multicolumn{2}{|c|}{ Jumlah }} \\
\hline & \multicolumn{2}{|c|}{ TWA-1 } & \multicolumn{2}{|c|}{ TWA-2 } & \multicolumn{2}{|c|}{ CA-1 } & \multicolumn{2}{|c|}{$\mathrm{CA}-2$} & & \\
\hline & AT & FT & AT & FT & AT & FT & AT & FT & AT & FT \\
\hline \multicolumn{11}{|l|}{ Lamiinae } \\
\hline \multicolumn{11}{|l|}{ Monochamini } \\
\hline Acalolepta rusticatrix & 5 & 8 & 4 & 9 & 0 & 0 & 9 & 10 & 18 & 27 \\
\hline Epepeotes lucus & 2 & 0 & 0 & 0 & 0 & 1 & 1 & 0 & 3 & 1 \\
\hline Myagrus javanicus & 2 & 2 & 0 & 1 & 0 & 0 & 0 & 0 & 2 & 3 \\
\hline Cereopsius javanus & 1 & 0 & 0 & 0 & 0 & 0 & 0 & 0 & 1 & 0 \\
\hline \multicolumn{11}{|l|}{ Mesosini } \\
\hline Cacia curta & 1 & 0 & 2 & 0 & 0 & 0 & 1 & 0 & 4 & 0 \\
\hline Cacia herbaceae & 1 & 0 & 2 & 0 & 0 & 0 & 0 & 0 & 3 & 0 \\
\hline \multicolumn{11}{|l|}{ Gnomini } \\
\hline Gnoma confusa & 4 & 3 & 6 & 1 & 0 & 0 & 7 & 2 & 17 & 6 \\
\hline \multicolumn{11}{|l|}{ Apomecynini } \\
\hline Atimura bacillina & 2 & 0 & 0 & 0 & 56 & 7 & 1 & 1 & 59 & 8 \\
\hline Sybra alternans & 0 & 4 & 0 & 0 & 12 & 5 & 3 & 1 & 15 & 10 \\
\hline Sybra fuscotriangularis & 1 & 0 & 0 & 0 & 0 & 0 & 1 & 0 & 2 & 0 \\
\hline Sybra lateralis & 0 & 0 & 0 & 0 & 1 & 0 & 0 & 0 & 1 & 0 \\
\hline Sybra binotata & 28 & 29 & 31 & 14 & 38 & 45 & 30 & 14 & 127 & 102 \\
\hline Sybra obliquefasciata & 0 & 0 & 0 & 0 & 0 & 0 & 2 & 0 & 2 & 0 \\
\hline \multicolumn{11}{|l|}{ Nyctimeniini } \\
\hline Nyctimenius javanus & 12 & 17 & 26 & 10 & 1 & 4 & 0 & 4 & 39 & 35 \\
\hline \multicolumn{11}{|l|}{ Pteropliini } \\
\hline Pterolophia uniformis & 6 & 2 & 1 & 0 & 11 & 5 & 0 & 0 & 18 & 7 \\
\hline Pterolophia triangularis & 5 & 3 & 1 & 0 & 0 & 0 & 2 & 0 & 8 & 3 \\
\hline Pterolophia melanura & 2 & 5 & 4 & 1 & 10 & 9 & 3 & 1 & 19 & 16 \\
\hline Pterolophia secuta & 1 & 0 & 0 & 0 & 1 & 0 & 0 & 0 & 2 & 0 \\
\hline \multicolumn{11}{|l|}{ Pogonocherini } \\
\hline Exocentrus artocarpi & 0 & 0 & 0 & 0 & 0 & 0 & 1 & 0 & 1 & 0 \\
\hline \multicolumn{11}{|l|}{ Agaphantiini } \\
\hline Pothyne vittata & 1 & 6 & 0 & 8 & 0 & 0 & 0 & 0 & 1 & 14 \\
\hline Jumlah individu & 74 & 79 & 77 & 44 & 130 & 76 & 61 & 33 & 342 & 232 \\
\hline Jumlah total & \multicolumn{2}{|c|}{153} & \multicolumn{2}{|c|}{121} & \multicolumn{2}{|c|}{206} & \multicolumn{2}{|c|}{94} & \multicolumn{2}{|c|}{574} \\
\hline
\end{tabular}

Tabel 2. Indeks keanekaragaman $\left(\mathrm{H}^{\prime}\right)$, kemerataan (E), dan dominansi (D) kumbang cerambycid di Pangandaran. TWA: Taman Wisata Alam; CA: Cagar Alam

\begin{tabular}{lcccc}
\hline Indeks keanekaragaman & TWA-1 & TWA-2 & CA-1 & CA-2 \\
\hline Shannon-Wiener (H') & 2,09 & 1,70 & 1,52 & 1,75 \\
Indeks kemerataan (E) & 0,74 & 0,71 & 0,69 & 0,68 \\
Indeks dominansi (D) & 0,20 & 0,25 & 0,28 & 0,28 \\
Jumlah spesies & 17 & 11 & 9 & 13 \\
\hline
\end{tabular}




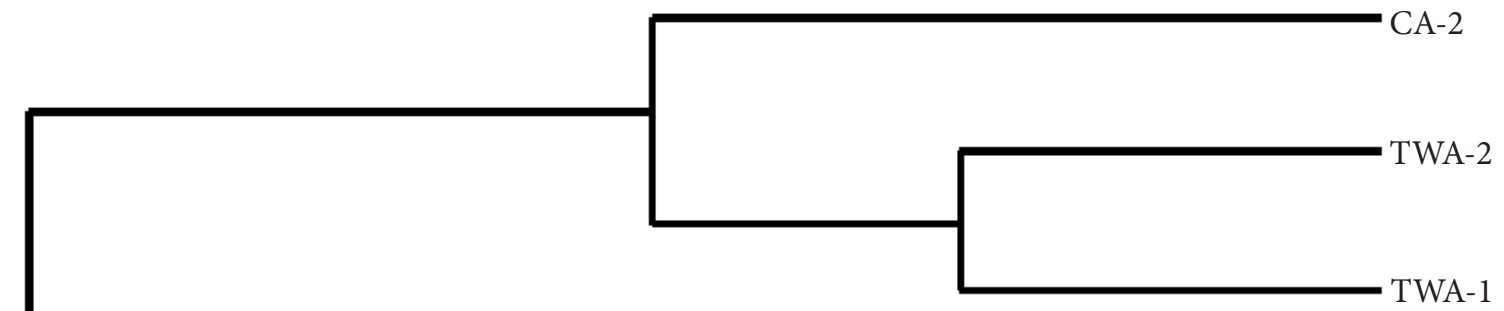

CA-1

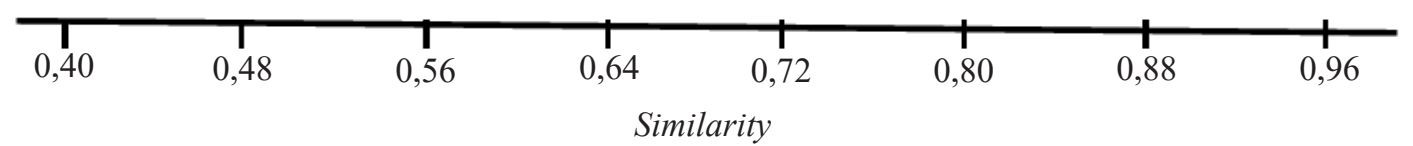

Gambar 1. Dendogram kesamaan komunitas kumbang cerambycid berdasarkan analisis UPGMA dengan menggunakan kesamaan Bray-Curtis. TWA: Taman Wisata Alam; CA: Cagar Alam.
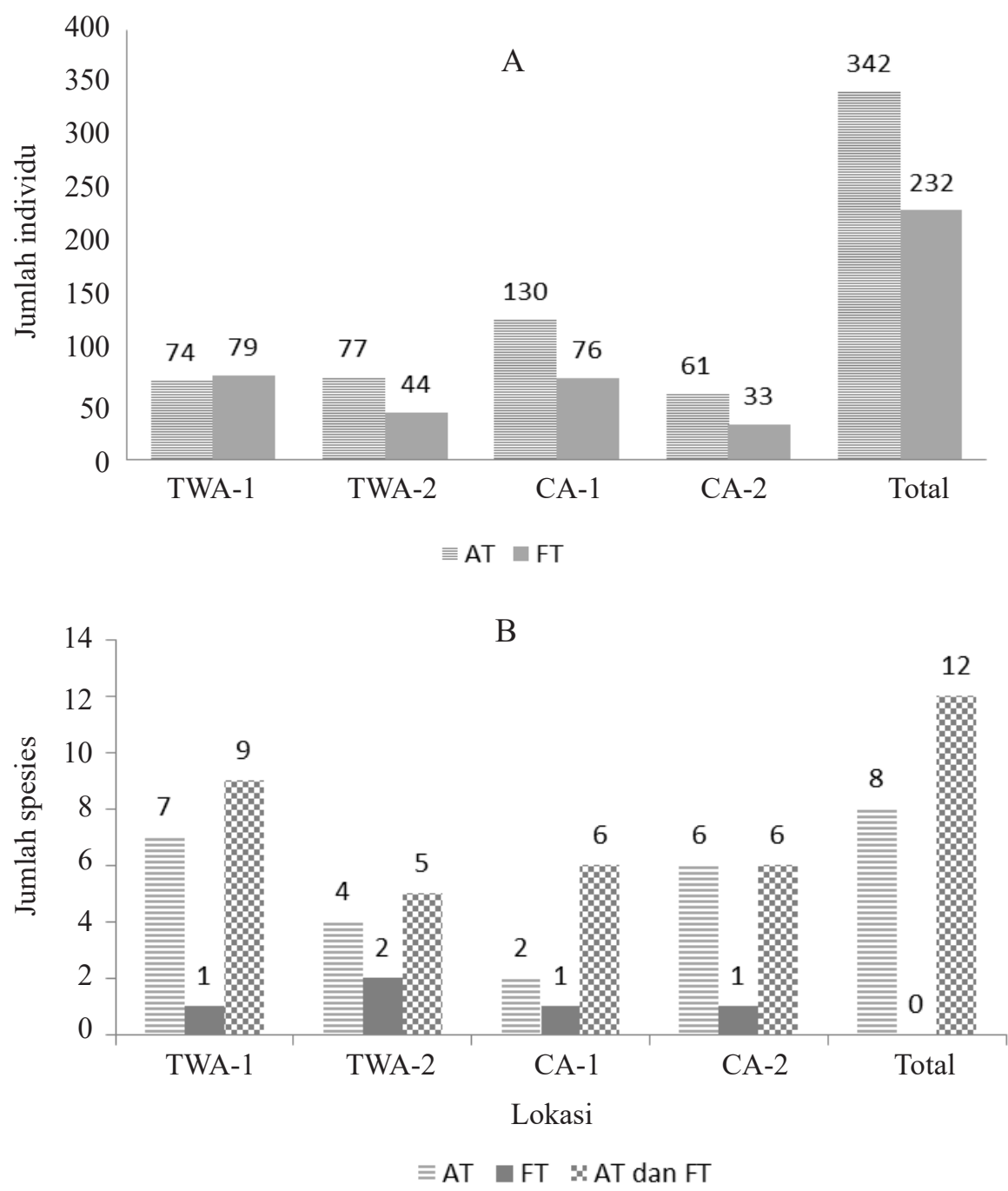

Gambar 2. Jumlah individu (A) dan jumlah spesies (B) kumbang cerambycid yang dikoleksi dengan Artocarpus trap (AT) dan Ficus trap (FT). TWA: Taman Wisata Alam; CA: Cagar Alam, 1 dan 2 menunjukkan lokasi ke-1 dan ke-2. 

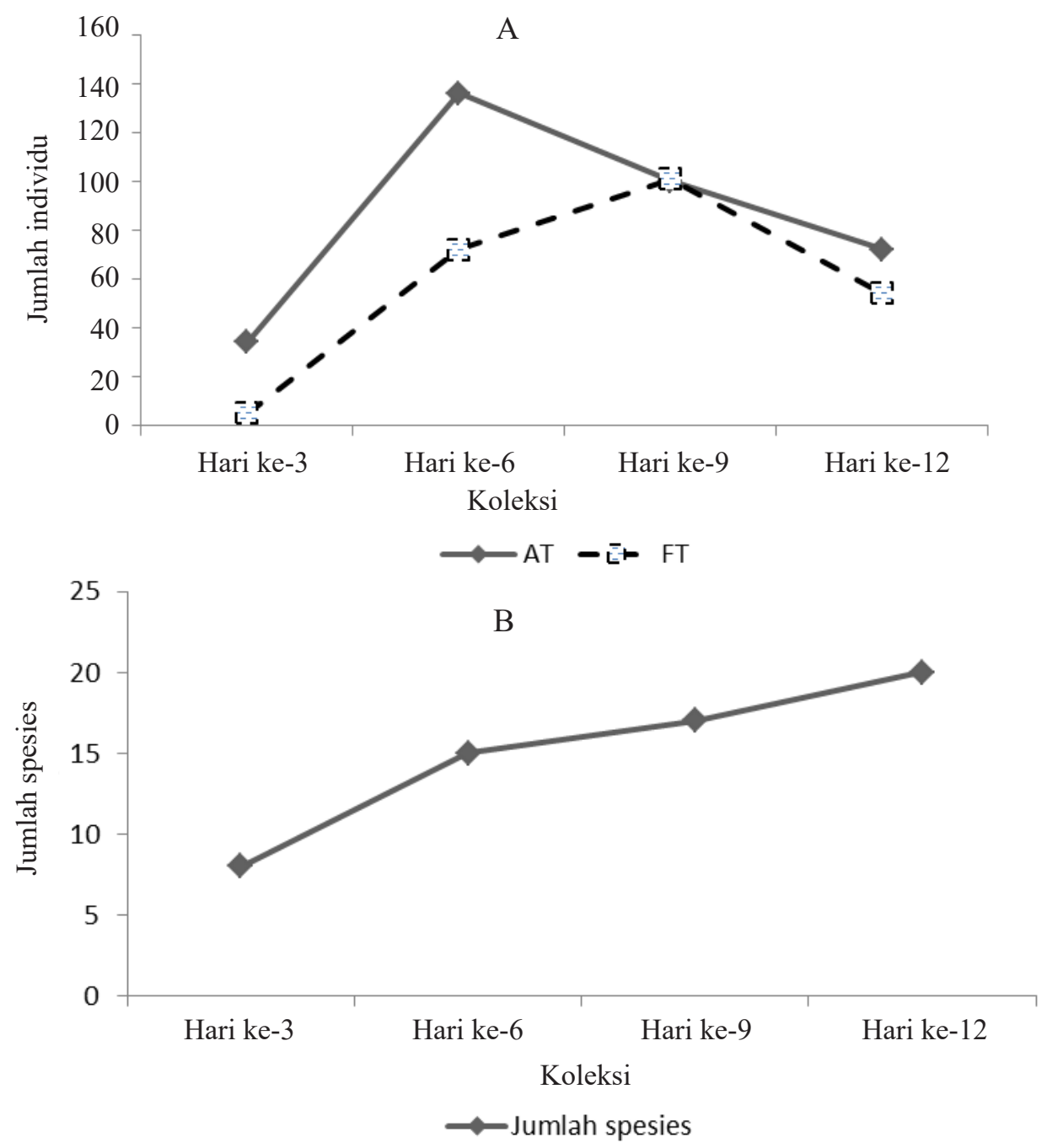

Gambar 3. Jumlah individu kumbang cerambycid yang dikoleksi dengan perangkap Artocarpus (AT) dan perangkap Ficus (FT) (A) dan jumlah kumulatif spesies kumbang yang dikoleksi pada hari ke-3 sampai hari ke-12 (B).

bentuk tubuh memanjang, bersisi sejajar, silindris, pronotum menyempit dari dasar elitra (Borror et al. 1989), dan muka tampak datar (flat-faced) (Ponpinij et al. 2011). Kumbang ini memiliki warna dan ukuran beragam. Di Asia Tenggara, kumbang Lamiinae telah teridentifikasi sebanyak 180 genus dan masih banyak spesies yang belum teridentifikasi (Fah 2010). Di Borneo, kumbang Lamiinae telah terdeskripsi sebanyak 22 tribe (Heffern 2013). .

Kumbang cerambycid yang ditemukan dominan di kawasan Pangandaran ialah Sybra, Atimura, dan Pterolophia yang umumnya berukuran tubuh kecil. Dalam Genus Sybra, spesies yang memiliki kelimpahan tinggi adalah $S$. binotata (229 individu), S. alternans (25 individu), sedangkan Pterolophia yang banyak ditemukan adalah $P$. melanura (35 individu) dan $P$. uniformis (25 individu). Kumbang $S$. binotata dan P. melanura ditemukan di semua lokasi pengamatan. Keempat spesies tersebut banyak ditemukan di lokasi CA-1 yang merupakan kawasan terbuka. Genus Sybra memiliki sebaran yang luas, meliputi Indonesia, Philipina, Micronesia, hingga kepulauan Hawaii (Chen et al. 2001). Sybra juga ditemukan dominan di hutan karet di Jambi, Sumatera (Fahri et al. 2016). Genus ini banyak ditemukan pada ranting atau cabang kering dari tumbuhan Euphorbia, Barringtonia, Cycas, Hibiscus, Artocarpus, dan Ficus. Dominansi Sybra dan Pterolophia di lokasi penelitian berkaitan dengan ukuran tubuh yang kecil sehingga larva dapat hidup pada ranting atau batang kecil (Fahri et al. 2016). Spesies ini memiliki laju reproduksi yang tinggi dan lebih tahan terhadap kerusakan habitat. Tscharntke et al. (2002) melaporkan spesies yang berukuran besar 
umumnya mempunyai laju reproduksi yang lambat dan lebih rentan terhadap kerusakan habitat. Spesies lain yang ditemukan dominan di lokasi CA-1 adalah A. bacillina (63 individu) dengan panjang tubuh sekitar $1,4 \mathrm{~cm}$. Menurut Noerdjito et al. (2009), A. bacillina dapat digunakan sebagai indikator pada hutan yang terdegradasi akibat penebangan, kebakaran, dan alih fungsi lahan. Genus Acalolepta dan Epepeotes banyak ditemukan di hutan primer atau hutan sekunder yang dapat digunakan sebagai indikator hutan yang belum terdegradasi. Kumbang A bacillina juga ditemukan di tiga tipe habitat di Jambi, yaitu hutan-karet, tebangan hutan-karet, dan kebun karet (Fahri et al. 2016).

Berdasarkan indeks Shannon-Wienner, keanekaragaman kumbang cerambycid tertinggi terdapat di lokasi TWA-1, diikuti CA-2, TWA2, dan CA-1. Di lokasi CA-1, ditemukan paling banyak jumlah individu (206 individu), namun memiliki nilai indeks paling kecil $\left(\mathrm{H}^{\prime}=1,52\right)$ karena terdapat dua spesies dominan ( $S$. binotata dan A. bacillina). Dominansi dua spesies tersebut ditunjukkan dari nilai indeks dominansi yang tinggi $(\mathrm{D}=0,28)$ dengan nilai kemerataan yang rendah $(E=0,69)$. Berdasarkan analisis UPGMA menggunakan indeks kesamaan Bray-Curtis, kemiripan spesies kumbang di TWA-1 dan TWA2 sangat tinggi $(>80 \%)$. Kumbang yang ditemukan di lokasi CA-2 mempunyai 65\% kemiripan dengan spesies kumbang di TWA. Kemiripan komposisi kumbang di tiga lokasi tersebut berkaitan dengan kemiripan habitat tersebut, yaitu hutan yang didominasi oleh pohon besar dengan tutupan tajuk yang rapat ( $L$. indica, $C$. odorata, P. javanicum, P. viridiflora, Casearia sp., dan T. grandis). Spesies kumbang yang dominan ditemukan di tiga lokasi tersebut adalah A. rusticatrix, G. confusa, S. binotata, $N$. javanus, dan $P$. vittata. Kumbang A. rusticatrix, $G$. confusa, dan $P$. vittata merupakan spesies yang berukuran besar (panjang tubuh $>10 \mathrm{~mm}$ ). Spesies ini tidak ditemukan di lokasi CA-1 yang merupakan daerah terbuka. Spesies kumbang di CA-1 memiliki kemiripan yang rendah (40\%) dengan TWA dan CA-2. Lokasi CA-1 merupakan kawasan terbuka dengan intensitas cahaya yang tinggi. Kumbang yang dominan di lokasi ini adalah A. bacillina, S. binotata, S. alternans,
P. uniformis, dan P. melanura yang berukuran tubuh kecil dan mampu beradaptasi di daerah terbuka (Noerdjito 2010). Secara umum, kumbang cerambycid yang ditemukan di kawasan Pangandaran mempunyai ukuran tubuh lebih kecil dibandingkan dengan kumbang dari Gunung Halimun (Makihara \& Noerdjito 2002) dan Gunung Slamet (Noerdjito 2011).

Spesies kumbang cerambycid yang ditemukan di kawasan Pangandaran memiliki kesamaan dengan hasil penelitian di beberapa kawasan di Jawa dan Sumatera. Dari 20 spesies yang ditemukan dalam penelitian ini, 8 spesies $(A$. rusticatrix, A. bacillina, E. lucus, $P$. melanura, $P$. uniformis, S. binotata, S. fuscotriangularis, dan S. obliquefasciata) ditemukan di Gunung Salak (Noerdjito 2012), 6 spesies (A. rusticatrix, E. lucus, $P$. vittata, $P$. melanura, $S$. binotata, dan $S$. fuscotriangularis) ditemukan di Gunung Slamet (Noerdjito 2011), dan 6 spesies (A. rusticatrix, E. lucus, A. bacillina, S. lateralis, P. melanura, dan P. secuta) ditemukan di Jambi (Fahri et al. 2016). Spesies A. rusticatrix, $N$. javanus, dan P. melanura merupakan spesies yang dapat hidup di berbagai tipe habitat dengan sebaran yang luas (Noerdjito 2010).

Penelitian ini menemukan 7 spesies kumbang endemik Jawa, yaitu M. javanicus, $C$. curta, S. obliquefasciata, S. fuscotriangularis, $P$. triangularis, $N$. javanus, dan E. artocarpi (Bezark 2015). Distribusi kumbang cerambycid dipengaruhi oleh vegetasi dan ketinggian lokasi. Selain itu, kondisi mikroklimat terutama suhu dan kelembapan udara juga mempengaruhi komposisi spesies kumbang di suatu habitat (Errouissi et al. 2004).

Kumbang cerambycid yang dikoleksi dengan perangkap Artocarpus lebih banyak dan umumnya berukuran lebih kecil dibandingkan dengan perangkap Ficus. Noerdjito et al. (2003) melaporkan perangkap Artocarpus lebih efektif untuk koleksi kumbang cerambycid. Spesies kumbang yang dikoleksi dengan perangkap Ficus umumnya yang berukuran besar, seperti A. rusticatrix dan $P$. vittata. Diduga, senyawa sekunder pada daun Artocarpus dan Ficus menjadi faktor penarik kumbang ini. Perlu analisis lebih lanjut tentang komposisi senyawa sekunder pada daun kedua spesies tersebut. 
Jumlah individu kumbang yang dikoleksi paling banyak pada hari ke-6 dengan perangkap Artocarpus dan hari ke-9 dengan perangkap Ficus. Pada hari ke 6, sejalan dengan mulai layu daun Artocarpus, makin banyak kumbang yang tertarik. Pada hari ke 12, jumlah individu kumbang yang dikoleksi dengan perangkap Artocarpus (72 individu) juga lebih banyak dibandingkan dengan perangkap Ficus (54 individu). Oleh karena itu, perangkap Artocarpus lebih efektif untuk koleksi kumbang cerambycid dibandingkan perangkap Ficus. Kumbang ini tertarik kayu atau cabang lapuk untuk mencari pasangan dan meletakan telur (Noerdjito 2012). Kumbang lain, seperti Monochamus tertarik pada kayu bekas tebangan untuk meletakkan telur (Hanks et al. 1998), sedangkan Gnoma boisduvali Plavilstshikov tertarik getah cabang yang baru dipangkas (Hawkeswood \& Dauber 1992).

\section{KESIMPULAN}

Di Cagar Alam Pangandaran telah teridentifikasi 20 spesies kumbang cerambycid dengan tiga genus dominan, yaitu Sybra, Atimura, dan Pterolophia. Lokasi yang didominasi pohon dengan tajuk rapat, seperti daerah Taman Wisata Alam-1, memiliki keanekaragaman kumbang tinggi, sedangkan daerah yang lebih terbuka, seperti Cagar Alam-1 memiliki keanekaragaman rendah. Daerah terbuka umumnya dihuni oleh kumbang berukuran kecil, seperti S. binotata dan A. bacillina. Tujuh spesies kumbang cerambycid yang ditemukan di kawasan Pangandaran, yaitu M. javanicus, C. curta, S. obliquefasciata, S. fuscotriangularis, P. triangularis, $N$. javanus, dan E. artocarpi merupakan spesies endemik Jawa. Penggunaan perangkap Artocarpus lebih efektif untuk koleksi kumbang cerambycid dibandingkan perangkap Ficus.

\section{DAFTAR PUSTAKA}

Borror DJ, Triplehorn CA, Johnson NF. 1989. An Introduction to The Study of Insects. Amerika: Saunders College.
Bezark LG. 2015. A photographic catalog of the Cerambycidae of the world. Tersedia pada: https:// apps2.cdfa.ca.gov/publicApps/plant/bycidDB/ wdefault.asp? $\mathrm{w}=\mathrm{O}$ [diakses 1 April 2015]. Chen H, Ota A, Fonsah GE. 2001. Infestation of Sybra alternans (Cerambycidae: Coleoptera) in Hawaii Banana Plantation. Hawaiian Entomology Society 35:119-122.

Cherepanov AI. 1990. Cerambycidae of Northern Asia. Dhote AK, penerjemah; Kothekar VS (Eds.). New Delhi: Amerind Publishing Co. Pvt. Ltd. Terjemahan dari: Usachi Severnoi Azii (Lamiinae). Volume ke-3 Part I.

Errouissi FS, Haloti PJ, Robert AJ, Idrissi, Lumaret JP. 2004. Effects of the attractiveness for dung beetles of dung pat origin and size along a climate gradient. Environment Entomology 33:45-53. doi: https://doi.org/10.1603/0046-225X-33.1.45.

Fah CL. 2010. Introduction of longhorn beetle. Subfamily Lamiinae. Longhorn beetles of Singapore. Tersedia pada: http://www. singaporeinsects.com/references.htm [diakses 11 February 2015].

Fahri, Atmowidi T, Noerdjito WA. 2016. Diversity and abundance of cerambycid beetles in the four major land-use types found in Jambi Province, Indonesia. HAYATI Journal of Biosciences 23:56-61. doi: https://doi.org/10.1016/j. hjb.2016.06.001.

Hammer, Øyvind, Harper, David AT, Ryan PD. 2001. Past: Paleontological statistics software package for education and data analysis. Palaeontologia Electronica 4:1-9.

Hanks LM, Millar JG, Paine TD. 1998. Dispersal of the Eucalyptus longhorned borer (Coleoptera: Cerambycidae) in urban landscapes. Environmental Entomology 27:1418-1424. doi: https://doi.org/10.1093/ee/27.6.1418.

Hawkeswood TJ, Dauber D. 1992. Review of the biology, distribution and taxonomic history of Gnoma boisduvali Plavilstshikov, a longicorn beetle from the rain forests of Papua New Guinea and Irian Jaya. Spixiana 15:253-260.

Heffern DJ. 2013. A Catalog and Bibliography of Longhorned Beetles from Borneo (Coleoptera: Cerambycidae, Disteniidae and Vesperidae) [bibliografi]. Electronic Version, 2013.1.

Koneri R, Solihin DD, Buchori D, Tarumingkeng R. 2010. Keanekaragaman kumbang Lucanid (Coleoptera: Lucanidae) pada berbagai ketinggian tempat di Hutan Konsensi Unocal Gunung Salak, Jawa Barat. Jurnal Matematika dan Sains 15:77-84. 
La Mantia T, Bellavista M, Giardina G, Sparacio I. 2010. Longhorn beetles of the Ficuzza (W Sicily, Italy) and their relationship with plant diversity. Biodiversity Journal 1:15-44.

Magurran AE. 2004. Measuring Biological Diversity. Oxford: Blackwell Science.

Makihara H. 1999. Atlas of longicorn beetles in Bukit Soeharto Education Forest, Mulawarman University, East Kalimantan, Indonesia. Pusrehut Special Publication 7:1-40.

Makihara H, Noerdjito WA. 2002. Longicorn beetles from Gunung Halimun National Park, West Java, Indonesia from 1997-2002 (Coleoptera: Disteniidae and Cerambycidae). Bulletin of the FFPRI 1:189-223.

Noerdjito WA, Makihara H, Sugiharto. 2003. How to find outindicated cerambycid spesies for forest condition status and case of Gunung Halimun National Park, West Java and Bukit Bingkarai Forest, East Kalimantan. Di dalam: The Landscape Level Rehabilitation of Degraded Tropical Forest (Tsukuba, 18-19 Februari 2003). hlm.57-60. Tsukuba: FFPRI.

Noerdjito WA, Makihara H, Sugiharto. 2004. Differences of cerambycid fauna with fragment of primary, secondary and degraded forest in landscape affected by human impacts and fire disturbance, East Kalimantan, Indonesia. Di dalam: The Landscape Level Rehabilitation of Degraded Tropical Forest (Tsukuba, 2-3 Marchi 2004). hlm.63-73. Tsukuba: FFPRI.

Noerdjito WA, Makihara H, Matsumoto K. 2005. Longicorn beetle fauna (Coleoptera, Cerambycidae) collected from Friendship Forest at Sekaroh, Lombok. The Landscape Level Rehabilitation of Degraded Tropical Forest (Tsukuba, 22-23 February 2005). hlm. 55-64. Tsukuba: FFPRI.
Noerdjito WA. 2008. Community structure of longhorn beetles (Coleoptera: Cerambycidae) in the area of Mount Ciremai National Park. Jurnal Biologi Indonesia 4:371-384.

Noerdjito WA, Makihara H, Sugiharto. 2009. Evaluation of various forest conditions based on longhorn beetles (Coleoptera: Cerambycidae) as bio-indicators in East Kalimantan. Di dalam: CDM Plantation and Biodiversity (Tsukuba, 24 February 2009). hlm. 31-39. Tsukuba: FFPRI.

Noerdjito WA. 2010. Arti Kebun Raya Bogor bagi kehidupan kumbang antena panjang (Coleoptera, Cerambycidae). Jurnal Biologi Indonesia 6:289292.

Noerdjito WA. 2011. Evaluasi kondisi hutan berdasarkan keragaman kumbang antena panjang (Coleoptera, Cerambycidae) di kawasan Gunung Slamet. Berita Biologi 10:521-531.

Noerdjito WA 2012. Dampak kegiatan manusia terhadap keragaman dan pola distribusi kumbang sungut panjang (Coleoptera: Cerambycidae) di Gunung Salak, Jawa Barat. Jurnal Biologi Indonesia 8:57-69.

Ponpinij S, Hormchan P, Rojanavongse V. 2011. Checklist of new records of Subfamily Lamiinae (Coleorptera: Cerambycidae) in Northern Thailand. Kasetsart Journal (Natural Science) 45:841-855.

Priawandiputra W, Tsuji Y, Widayati KA, Suryobroto B. 2020. Dung beetle assemblages in lowland forests of Pangandaran Nature Reserve, West Java, Indonesia. Biodiversitas 21:497-504.

Tscharntke T, Dewenter IS, Kruess A, Thies C. 2002. Characteristics of insect populations on habitat fragments: A mini review. Ecological Research 17:229-239. doi: https://doi.org/10.1046/j.14401703.2002.00482.x. 